\title{
Est1 has the properties of a single-stranded telomere end-binding protein
}

\author{
Valerie Virta-Pearlman, ${ }^{1}$ Danna K. Morris, ${ }^{2}$ and Victoria Lundblad ${ }^{1,2,3}$ \\ ${ }^{1}$ Department of Molecular and Human Genetics and ${ }^{2}$ Department of Cell and Molecular Biology, Baylor College of \\ Medicine, Houston, Texas 77030 USA
}

In Saccharomyces cerevisiae, deletion of the EST1 gene results in phenotypes identical to those displayed by a deletion of a known component of telomerase (the yeast telomerase RNA), arguing that EST1 is also critical for telomerase function. In this study, we show that the Est1 protein binds to yeast G-rich telomeric oligonucleotides in vitro. Binding is specific for single-stranded substrates and requires a free $3^{\prime}$ terminus, consistent with the properties expected for a protein bound to the $3^{\prime}$ single-stranded G-rich extension present at the telomere. Assessment of the in vivo function of this single-stranded DNA-binding protein has shown that EST1 acts in the same pathway of telomere replication as the TLC1 telomerase RNA, by several different genetic criteria: est1 tlc1 double mutant strains show no enhancement of phenotype relative to either single mutant strain, and EST1 dominant mutations have an effect on telomeric silencing similar to that displayed by TLC1 previously. We propose that Est1 is a telomere end-binding protein that is required to mediate recognition of the end of the chromosome by telomerase.

[Key Words: Est1; telomeres; senescence; DNA binding; telomerase]

Received July 15, 1996; revised version accepted November 8, 1996.

The synthesis and maintenance of telomeres requires the enzyme telomerase as well as other telomeric DNA binding proteins (for review, see Blackburn and Greider 1995; Zakian 1995; Greider 1996). Telomerase is a specialized reverse transcriptase that elongates the G-rich strand of chromosomal termini by using a region of its internal RNA component as a template to dictate the sequence of the newly synthesized telomeric DNA (Greider and Blackburn 1989; Yu et al. 1990; Singer and Gottschling 1994; Feng et al. 1995; McEachern and Blackburn 1995). After the G-rich strand is elongated by telomerase, the complementary C-rich strand is thought to be replicated by conventional DNA polymerases, although telomere-specific proteins may regulate this process (Zahler and Prescott 1989; Vermeesch and Price 1994).

The end of the chromosome has been shown in a number of species to terminate with a single-stranded extension of the G-rich strand, which is complexed with proteins specific for this structure (for review, see Fang and Cech 1995; Henderson 1995). The most well characterized telomere end-binding proteins are from the ciliates Oxytricha and Euplotes, which specifically bind the 3' single-stranded extension of the $\mathrm{T}_{4} \mathrm{G}_{4}$-containing strand, thereby protecting the telomeric DNA from Bal31-mediated nuclease digestion and chemical modification (Gottschling and Zakian 1986; Price and Cech 1987;

${ }^{3}$ Corresponding author.
Price 1990|. Similar factors with the properties expected of a terminus-specific binding activity have also been identified in extracts from Xenopus and Tetrahymena (Cardenas et al. 1993; Sheng et al. 1995). These proteins potentially could play multiple roles in vivo at the telomere: They have been proposed to provide a cap against degradation of the telomere and they may regulate telomerase, either positively or negatively (Gray et al. 1991; Price 1992; Shippen et al. 1994; Vermeesch and Price 1994). However, the absence of reverse genetic techniques in these organisms has prevented a direct test of either of these hypotheses. Yeast has also been predicted to have telomere end-binding proteins, based primarily on genetic criteria (Stavenhaven and Zakian 1994; McEachern and Blackburn 1995; Wiley and Zakian 19951, but efforts to identify proteins that display the expected features of an end-binding activity and an in vivo role in telomere maintenance have not been successful (Lin and Zakian 1994; Konkel et al. 1995).

In addition to telomere end-binding proteins, the enzyme telomerase must also bind the $3^{\prime}$ terminus of the extended G-rich strand to replicate and maintain the telomere. This enzyme has been studied most extensively in Tetrahymena; only in this species have both the RNA component as well as two protein subunits of the core enzyme been cloned (Greider and Blackburn 1989; Collins et al. 1995). In Saccharomyces cerevisiae, efforts to identify protein subunits of telomerase, like the attempts to identify a terminus-specific factor, have so far been unsuccessful. The best-characterized candidate for a telomerase protein component is the EST1 
gene of $S$. cerevisiae. This hypothesis has been based on the genetic phenotypes exhibited by est $1^{-}$strains: Deletion of EST1 results in progressive telomere shortening and a senescence growth phenotype, characteristics originally predicted for a defect in telomerase (Lundblad and Szostak 1989). These phenotypes are indistinguishable from those displayed by a strain with a deletion of the yeast telomerase RNA (Singer and Gottschling 1994; this work), arguing that EST1 is also essential, either directly or indirectly, for telomerase function. However, analysis of whether extracts prepared from est $1^{-}$strains are defective for telomerase activity has produced conflicting results. One report indicated that Est 1 was essential for enzymatic activity (Lin and Zakian 1995), whereas another study found that telomerase activity was still present at roughly wild-type levels in fractionated extracts prepared from a strain in which the EST1 gene was deleted (Cohn and Blackburn 1995). Although this contradiction could be the consequence of different assay conditions, the latter data argue that Estlp is not an essential part of the catalytic core of the enzyme (but do not exclude the possibility that Est 1 is a noncatalytic component of telomerase). A second set of studies has shown that the Est1 protein can be coimmunoprecipitated with the yeast telomerase RNA (Lin and Zakian 1995; Steiner et al. 1996). Because these experiments did not monitor the stoichiometry of the Estl-RNA interaction, these studies could not be used to definitively argue whether Estl was an integral component of the telomerase complex. Therefore, these studies have left open the precise role of Est 1 at the telomere.

We have analyzed purified Estl protein to determine whether it exhibits biochemical properties consistent with a direct role at the telomere. This approach has revealed that Estl has the properties of a single-stranded telomere DNA binding protein, with a specific requirement for a free $3^{\prime}$ terminus. Genetic analysis comparing EST1 and TLC1 has also demonstrated that EST1 is required for the telomerase-mediated pathway for maintaining the telomere. These results indicate that EST1 mediates the interaction of telomerase with the chromosomal terminus via its single-stranded end-binding activity.

\section{Results}

Est1 protein binds to single-stranded yeast telomeric DNA

To determine whether Est 1 acts directly at the telomere, we asked whether Est 1 protein could bind yeast telomeric substrates in vitro. Recombinant Estl protein containing a (His) ${ }_{6}$ tag at the amino terminus was purified as a soluble protein from Escherichia coli by Ni-NTA-agarose affinity purification. The resulting eluate exhibited a single prominent band (Fig. 1A), which was not present in mock preparations from a strain carrying a vector with no insert (data not shown). Immunological detection of the recombinant Est 1 protein /with anti-gene 10 antisera to detect a T7 gene 10 epitope fused in-frame at the Est 1 amino terminus) demonstrated that the purified protein

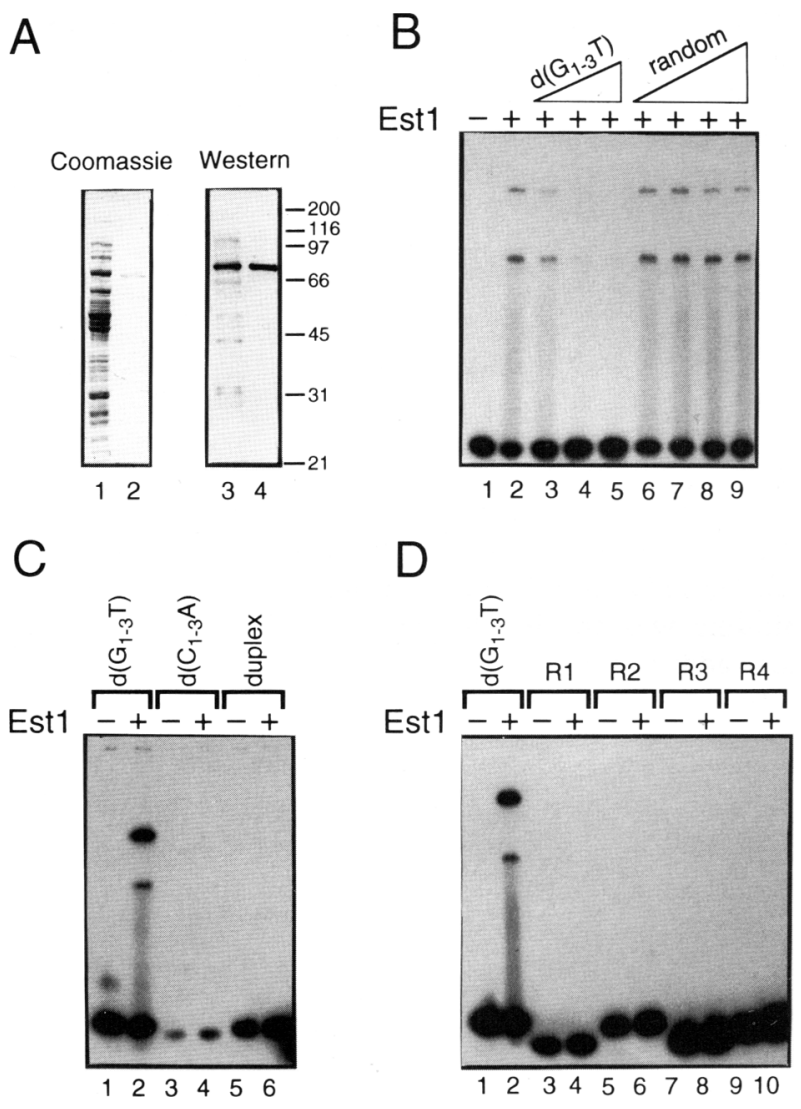

Figure 1. Est 1 protein binds yeast single-stranded telomeric substrates. (A) Amino-terminal (His) ${ }_{6}$ tagged-Estl protein was affinity purified as described in Materials and Methods. Extract supernatant (lanes 1,3) and the resulting Est l-containing eluate (lanes 2,4) separated by SDS-PAGE are shown after Coomassie blue staining and Western detection. $(B)$ Gel mobility shift assays with $200 \mathrm{~nm}$ purified Estl protein and $50 \mathrm{pm}$ end-labeled d(TGTGTGGG) $)_{3}$, unlabeled $\mathrm{d}\left(\mathrm{G}_{1-3} \mathrm{~T}\right)$ competitor was present at $0.2 \mathrm{nM}(4 \times), 1.0 \mathrm{nM}(20 \times)$, and $5.0 \mathrm{nM}(100 \times)$, and random sequence competitor (R1) at $0.2 \mathrm{~nm}, 1.0 \mathrm{nM}, 5.0 \mathrm{nM}$, and $10.0 \mathrm{~nm}$. $(C, D)$ Gel mobility shifts using the same reaction conditions as above, but with a different preparation of Estlp. The sequences of the substrates (all at $50 \mathrm{pM}$ ) are as follows: $\mathrm{d}\left(\mathrm{G}_{1-3} \mathrm{~T}\right)=$ $\mathrm{d}\left(\right.$ TGTGTGGG $_{3} ; \mathrm{d}\left(\mathrm{C}_{1-3} \mathrm{~A}\right)=\mathrm{d}(\mathrm{CCCACACA})_{3} ;$ duplex $=\mathrm{d}(\mathrm{TG}-$ $\mathrm{TGTGGG}_{3} / \mathrm{d}(\mathrm{CCCACACA})_{3} ; \mathrm{R} 1=\mathrm{d}(\mathrm{CACTATCGACTACG}-$ CGATCA); $\mathrm{R} 2=\mathrm{d}($ AGCGGATAACAATTTCACACAGGA); $\mathrm{R} 3=\mathrm{d}($ TAATACGACTCACTATAGGGAGA); $\mathrm{R} 4=\mathrm{d}(\mathrm{GGT}-$ CGTCAGACTGTCGATGAAGCC). Although the signal in lanes 3 and 4 in $C$ is under-represented, darker exposures of this and similar experiments showed no binding to the $d\left(C_{1-3} A\right)$ substrate.

was in fact Est 1 (Fig. 1A). The apparent molecular weight of the purified protein was $\sim 70 \mathrm{kD}$, somewhat smaller than the $86 \mathrm{kD}$ predicted for the recombinant protein. However, Est 1 protein preparations of identical observed molecular weight were obtained when the $(\mathrm{His})_{6}$ tag and gene 10 epitope were at the carboxyl terminus (data not shown), indicating that the discrepancy in size was not attributable to premature translation stops. The amino 
terminal- and carboxy terminal-tagged Estl proteins showed equivalent binding and competition behavior with telomeric and nontelomeric substrates (Fig. 5, below, and data not shown).

Figure $1 \mathrm{~B}$ shows that Estl protein formed specific complexes with a single-stranded yeast telomeric oligonucleotide d(TGTGTGGG) ${ }_{3}$, corresponding to a portion of a $S$. cerevisiae chromosomal telomere sequence (Shampay et al. 1984; Walmsley et al. 1984). Complex formation was specific for the Estl protein, as no binding was observed with eluate from a mock extract (Fig. 5, below). Estlp was capable of binding to several different variations of the yeast $d\left(G_{1-3} T\right)$ telomeric sequence (Fig. 4 , below, and data not shown/ but did not interact with the complementary C-rich telomeric strand or with a telomeric DNA substrate that was fully duplex (Fig. 1C). Binding was specific for the yeast G-rich oligomer, in that addition of excess cold yeast telomeric oligo competed effectively for formation of the Estl-telomeric DNA complex (Fig. 1B and 6B, below). In contrast, addition of $\leqslant 200$-fold molar excess of a single-stranded random sequence oligomer did not compete for binding (Fig. 1B), and no binding was observed with four random sequence oligomers similar in size to the telomeric oligo, with G-content ranging from $15 \%$ to $30 \%$ (Fig. 1D).

The mobility shift experiments in Figure 1 showed two different complexes forming with Est 1 protein. To investigate this in more detail, we examined the pattern of complex formation with increasing amounts of Est 1 protein, while holding the d(TGTGTGGG) ${ }_{3}$ oligomer concentration constant. Figure 2 shows that at low concentrations of Est 1 relative to substrate, only the faster migrating complex was formed, but increased protein concentration resulted in the appearance of a slower mi- grating complex, with a reduction in the faster migrating complex. This observation is consistent with a transition to a multimeric Est 1 complex at higher protein concentrations, although these data do not address the oligomerization state of either complex. A second observation pertinent to the two complexes was the presence of a continuous diffuse signal present below the lower band. The signal was diffuse rather than a series of discrete bands and continued to the position of unbound labeled oligo, which is not consistent with a set of breakdown products of Est 1 binding to the telomeric oligomer. Instead, it is most likely attributable to dissociation of the faster migrating complex during migration through the acrylamide gel and subsequent release of the labeled oligo. This indicates that the faster migrating complex is less stable than the slower migrating complex under these electrophoresis conditions. From quantitation of the titration experiment, we determined that the observed dissociation constant for Estl binding to the telomeric DNA oligomer is $250 \mathrm{nM}$, a relatively weak affinity for DNA. However, it is comparable to that of the Oxytricha $\alpha$-subunit by itself for single-stranded telomeric DNA, whereas the complete Oxytricha telomerebinding heterodimeric complex binds telomeric DNA much tighter (Fang et al. 1993); Estlp may also have a binding partner that increases its affinity for DNA.

\section{Binding requires a free $3^{\prime}$ terminus}

In vivo, the end of the chromosome terminates with the G-rich strand protruding as a 3 ' single-stranded extension (Klobutcher et al. 1981; Pluta et al. 1982; Henderson and Blackburn 1989; Wellinger et al. 1993, 1996). If the Est 1 binding activity described above reflects an in vivo
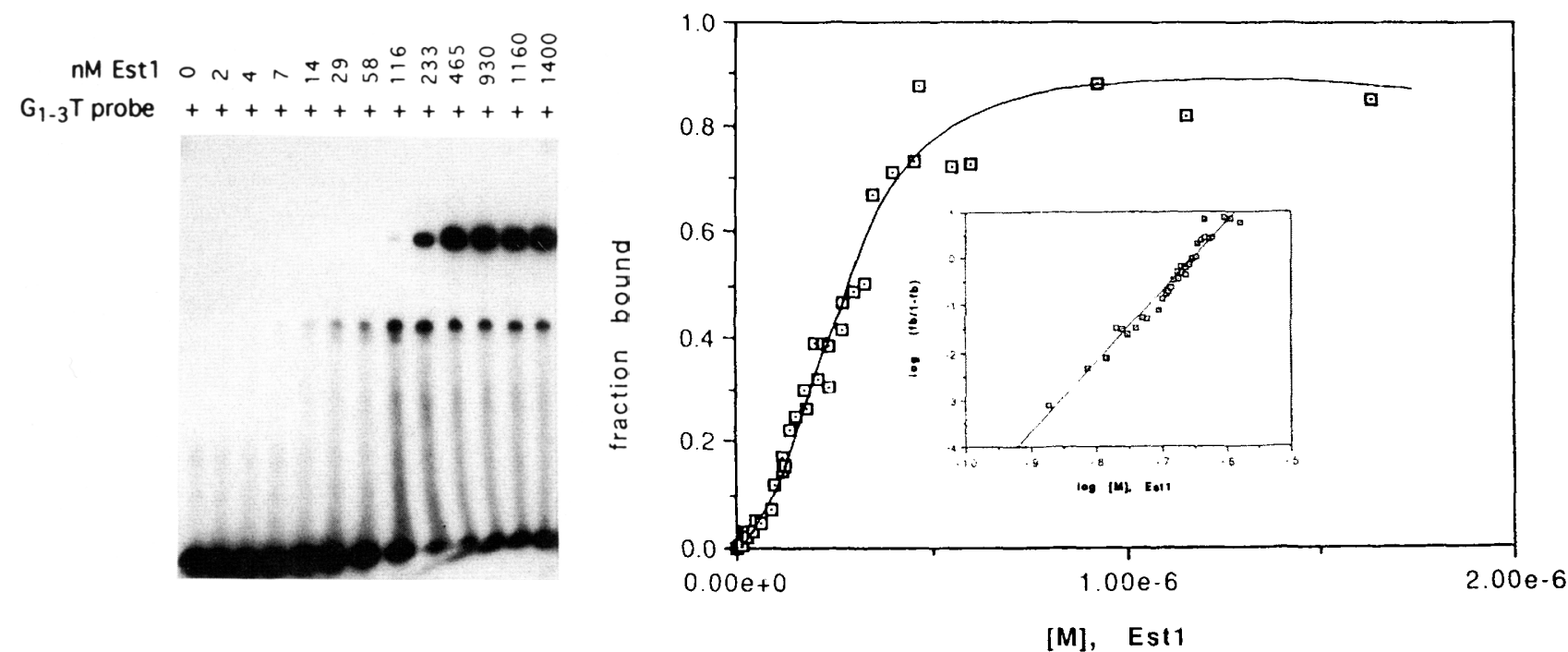

Figure 2. Estl protein forms two complexes with yeast telomeric oligomers. Telomeric DNA gel shifts were performed using a fixed concentration $(50 \mathrm{pM})$ of the d(TGTGTGGG) $)_{3}$ telomeric DNA oligomer and varying the concentration of Est 1 from 0 to $1400 \mathrm{nM}$. Quantitative data from Phosphorlmager analysis of more than four independent gel mobility shifts were used to determine equilibrium binding curve (plotted as the fraction of DNA bound vs. the ESTl concentration) and the resulting Hill plot (insert); a representative gel shift is shown. 
role at the $3^{\prime}$ end of the chromosome, one prediction is that this activity would require a free $3^{\prime}$ single-stranded terminus. To test this, completely single-stranded substrates were compared with partially duplex substrates in the gel shift binding assay. $\left(5^{\prime} \mathrm{R}\right)-\mathrm{Ye}$ and $\mathrm{Ye}-\left(3^{\prime} \mathrm{R}\right)$ are two single-stranded yeast telomeric oligonucleotides with 15 nucleotides of nontelomeric sequence added to the $5^{\prime}$ and $3^{\prime}$ termini of the d(TGTGTGGG) ${ }_{3}$ oligonucleotide, respectively. Both bound to Est 1 protein in a direct binding test (Fig. 3), although Ye-(3'R) was not capable of forming the faster migrating complex with Estlp (discussed below). Conversion of $\left(5^{\prime} \mathrm{R}\right)$-Ye to a molecule with $15 \mathrm{bp}$ of duplex at the $5^{\prime}$ end reduced binding only slightly relative to the fully single-stranded $\left(5^{\prime} \mathrm{R}\right)$-Ye oligo (Fig. 3, cf. lanes 4 and 8). In contrast, masking the single-stranded $3^{\prime}$ terminus of Ye- $\left(3^{\prime} \mathrm{R}\right)$ with $15 \mathrm{bp}$ of duplex DNA completely eliminated binding of Est 1 to this substrate (Fig. 3, cf. lanes 12 and 16). This demonstrates that Estl requires a free single-stranded $3^{\prime}$ end for binding to telomeric substrates, consistent with a role for Est 1 as a telomere end-binding protein in vivo.

\section{Est1 binds other G-rich telomeric substrates to variable extents}

As telomerase is capable of elongating telomeric primers from different organisms (Greider and Blackburn 1985; Morin 1989; Prowse et al. 1993; Mantell and Greider 1994), we examined whether Est 1 was capable of binding to nonyeast G-rich telomeric sequences. Single-

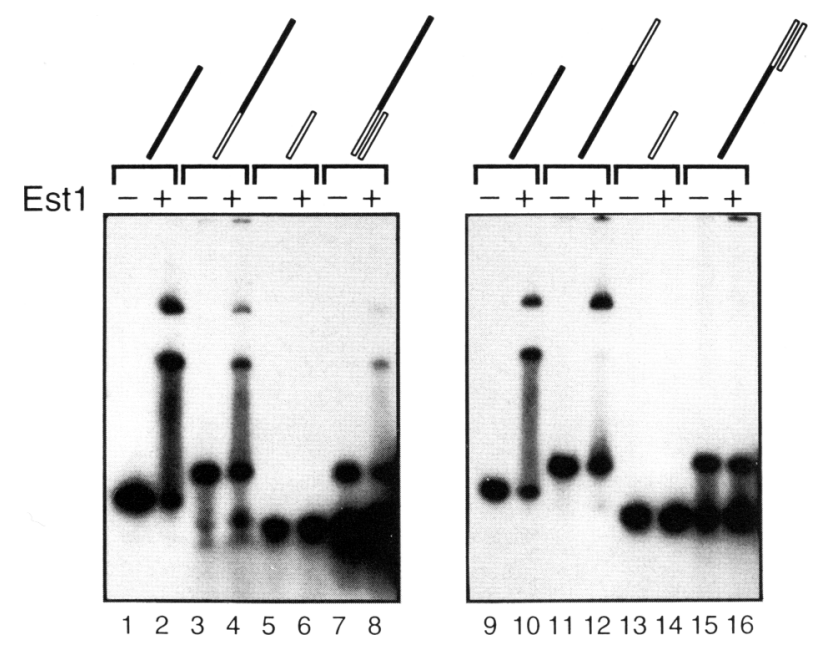

Figure 3. Binding is specific for a free $3^{\prime}$ terminus. Est1-telomeric DNA gel shifts of single-stranded and partially duplex substrates; see Materials and Methods for the details of the labeling of the partially duplex substrates. (Lanes 1,2,9,10) d(T-

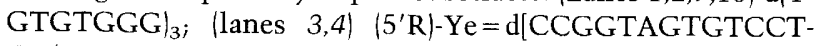
GG(TGTGTGGG) $)_{3}$; (lanes 5,6$) 5^{\prime} \mathrm{R}=\mathrm{d}(\mathrm{CCAGGACACTACC})$; (lanes 7,8) (5'R)-Ye annealed to 5'R; (lanes 11,12) Ye- $\left(3^{\prime} \mathrm{R}\right)=$ d $\left[(G G G T G T G T)_{3}\right.$ GGTCCTGTGATGGCC); (lanes 13,14) 3'R = d(GGCCATCACAGGACC); (lanes 15,16$)$ Ye- $\left(3^{\prime} \mathrm{R}\right)$ annealed to $3^{\prime} \mathrm{R}$. Although all oligos are shown here at $50 \mathrm{pm}$, no complex formation was observed with $\mathrm{Ye}-\left(3^{\prime} \mathrm{R}\right)$ annealed to $3^{\prime} \mathrm{R}$ even at 200 pM. (Solid bar) G-rich telomeric DNA; (open bar) nontelomeric DNA. stranded oligonucleotides corresponding to the Tetrahymena, human, and Oxytricha telomeric sequences were recognized to varying extents by Estl (Fig. 4A,B). Little or no complex formation was observed with both Tetrahymena and human telomeric oligos, whereas the $O x$ ytricha $\mathrm{d}\left(\mathrm{G}_{4} \mathrm{~T}_{4}\right)_{3}$ telomeric sequence [assayed at a fourfold higher oligo concentration, relative to the $\mathrm{d}\left(\mathrm{G}_{1_{-3}} \mathrm{~T}\right)$ oligomer] appeared to bind Estl to roughly the same degree as did the S. cerevisiae sequence (Fig. $4 \mathrm{~B}$ and data not shown). The efficiencies of these particular telomeric sequences to seed new telomere formation in vivo have not been tested relative to each other in the same experiment, although all three types of telomeric sequences provide a substrate at some level for the addition of yeast telomeric repeats (Pluta et al. 1984; Brown 1989; Lustig 1992). However, in an in vivo assay that semiquantitatively measures telomere healing onto yeast plasmids terminating with synthetic sequences, a $\mathrm{d}\left(\mathrm{G}_{1-3} \mathrm{TA}\right)$ oligo (related to the human repeat sequence tested here), and Tetrahymena telomeric sequences have been shown to be poor substrates relative to $d\left(\mathrm{G}_{1-3} \mathrm{~T}\right)$ (Lustig 1992).

To further explore the sequence specificity of Estlp telomeric binding, several variants of the yeast telomeric oligo, d(TGTGTGGG) ${ }_{3}$, were also tested. These oligos were assayed at $200 \mathrm{pM}$, fourfold higher than the concentration used with the yeast $\mathrm{d}\left(\mathrm{G}_{1-3} \mathrm{~T}\right)$ substrate, to help visualize the formation of weak complexes. The substrate d[GTG(TGTGGG) ${ }_{3}$ TGT], another variant of the $\mathrm{d}\left(\mathrm{G}_{1-3} \mathrm{~T}\right)$ sequence found at yeast telomeres, was equally competent at Estl complex formation (Fig. 4C and data not shown). However, the $\mathrm{d}\left(\mathrm{TG}_{1-5}\right)$ and $\mathrm{d}(\mathrm{TG})_{\mathrm{n}}$ oligos showed reduced binding to Estl, and binding was almost completely abolished with a $\mathrm{d}\left(\mathrm{G}_{1-3} \mathrm{~T}_{1-3}\right)$ oligo (Fig. $\left.4 \mathrm{C}\right)$. This shows that altering the sequence even slightly from that found in vivo at a yeast telomere, although still maintaining the same number of $G$ and $T$ residues as found in d(TGTGTGGG) ${ }_{3}$, has substantial effects on the ability to bind Estl protein.

For several of the non-d $\left(\mathrm{G}_{1-3} \mathrm{~T}\right)$ oligomers that were capable of binding Est 1 , only the slower migrating complex was observed (lanes 6 and 10 in Fig. 4B; lanes 6,8, and 10 in $4 \mathrm{C}$, and lane 12 in Fig. 3). The absence of the faster migrating complex suggests that formation of this less stable complex is further destabilized with less optimal substrates. In the case of the $Y e-\left(3^{\prime} R\right)$ substrate, which only differs from d(TGTGTGGG) ${ }_{3}$ by the addition of nontelomeric sequences at the $3^{\prime}$ terminus, this argues that the interaction of Est 1 with $3^{\prime} \mathrm{d}\left(\mathrm{G}_{1-3} \mathrm{~T}\right)$ sequence contributes to the stability of this complex. Although this hypothesis may also account for the absence of the faster migrating complex with some of the non$d\left(G_{1-3} T\right)$ substrates in Figure 4, we do not yet fully understand the substrate-dependent formation of these two complexes.

Est1 DNA binding maps to a carboxy-terminal region of the protein

To determine whether telomeric DNA binding activity 
Figure 4. Estlp binds to nonyeast telomeric oligonucleotides. DNA gel shift analyses used $200 \mathrm{nM}$ Est 1 protein and end-labeled single-stranded oligos. All oligos were used at $200 \mathrm{pm}$, to help visualize weak complex formation, with the exception of the $\mathrm{d}\left(\mathrm{G}_{1-3} \mathrm{~T}\right)$ oligo, which was at $50 \mathrm{pm}$; the same Estl preparation (also used in Fig. IC and 1D| was used for $A-C$. The substrates were $d\left(G_{1-3} \mathrm{~T}\right)=\mathrm{d}\left(\mathrm{TGTGTGGG}_{3} ;\right.$ Tet $_{4}$ or Tet $_{5}=4$ or 5 repeats of the Tetrahymena telomeric repeat sequence $d\left(T_{2} G_{4}\right)_{i} O_{x y}$ and $\mathrm{Oxy}_{3}=2$ or 3 repeats of the Oxytricha telomeric repeat sequence $\mathrm{d}\left(\mathrm{T}_{4} \mathrm{G}_{4}\right) ; \mathrm{Hu}_{3}$ or $\mathrm{Hu}_{4}=3$ or 4 repeats of the human telomeric repeat sequence $d\left(T_{2}-A_{3}\right) ; d\left(G_{1-3} T\right)$ variant $=\mathrm{d}\left[\mathrm{GTGl}\left(\mathrm{TGTG}_{3}\right)_{3} \mathrm{TGT}\right]_{;} \mathrm{d}\left(\mathrm{TG}_{12} ; \mathrm{d}\left(\mathrm{TG}_{1-5}\right)\right.$ $=\mathrm{d}\left(\right.$ TGTG $_{4}$ TGTGTG $_{5}$ TGTGTGT $) ; \mathrm{d}\left(\mathrm{T}_{1-3}\right.$ $\left.\mathrm{G}_{1-3}\right)=\mathrm{d}\left(\mathrm{G}_{3} \mathrm{TGT}_{2} \mathrm{G}_{3} \mathrm{TGTG}_{3} \mathrm{~T}_{3} \mathrm{GTG}_{3}\right)$.
A

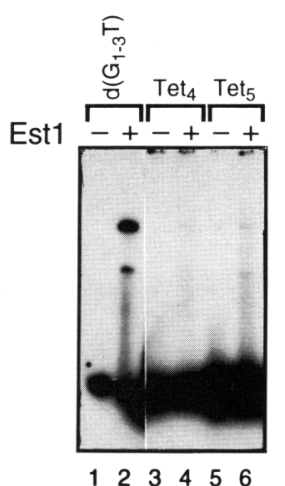

B

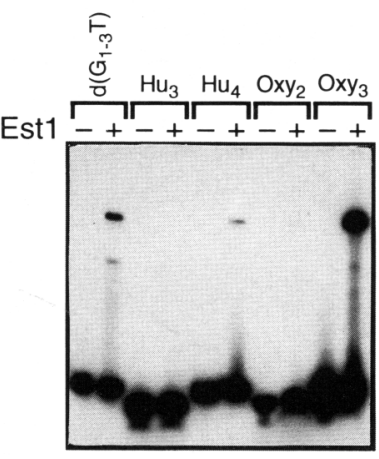

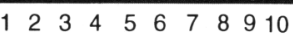

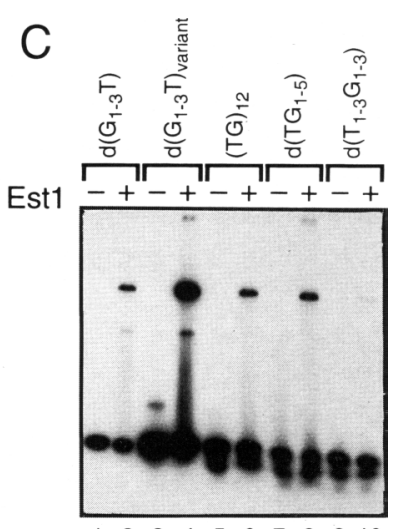

$\begin{array}{llllllllll}1 & 2 & 3 & 4 & 5 & 6 & 7 & 8 & 9 & 10\end{array}$ could be mapped to a specific region of the Est 1 protein, we constructed a panel of six deletion mutations that each removed $\sim 110$ amino acids. The in-frame deletions were constructed in an EST1-containing vector with the (His) ${ }_{6}$ tag at the carboxyl terminus to ensure that the proteins isolated after affinity purification were the desired deletion derivative and not a truncated version resulting from an unstable protein. Five of the six deleted proteins were still capable of binding telomeric DNA to a degree roughly comparable to that of the intact protein (Fig. 5). One deletion derivative, Estlp- $\Delta 14$, which removed 130 amino acids (amino acids 435-565), had greatly diminished DNA binding, indicating that the determinants for telomere DNA recognition reside in this region of the protein. The deletion encompassing this region was also defective in vivo for EST1 activity, as assayed genetically by a complementation assay, although this defect was not specific to this deletion; est1$\Delta 12$ and est $1-\Delta 13$ were also defective in vivo, whereas est1- $\Delta 15$ retained partial function (data not shown). The region defined by $\Delta 14$ may also contain additional properties essential for EST1 activity, as two missense mutations in this region that were capable of DNA binding in vitro were defective for EST1 function in vivo; these two mutations are discussed in more detail below. The 130-amino-acid region defined by this deletion analysis does not contain any previously identified DNA binding motifs; in particular, no sequence similarity has been observed between Estlp and previously identified proteins that bind to the single-stranded termini of ciliate telomeres (Fang and Cech 1991; Wang et al. 1992).

\section{Est1 protein exhibits a nonspecific RNA binding activity}

Several vertebrate proteins have been identified on the basis of their ability to bind single-stranded telomeric DNA and subsequently shown to be members of the het-

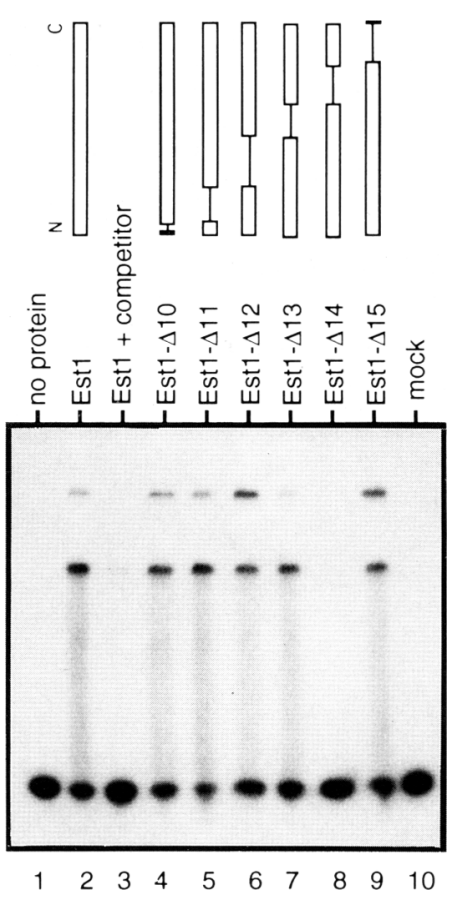

Figure 5. Est 1 DNA binding maps to a 130-amino-acid domain. Gel mobility shifts were conducted with $200 \mathrm{nM}$ Est 1 protein and $50 \mathrm{pm}$ end-labeled d(TGTGTGGG) ${ }_{3}$; all Estl constructs have the (His) 6 tag at the carboxyl terminus. (Lane 1) No Est 1 protein added; (lane 2) $200 \mathrm{~nm}$ full-length Estl protein; (lane 3) $200 \mathrm{~nm}$ full-length Est1 protein plus a 50-fold molar excess of cold d(TGTGTGGG) ${ }_{3}$ competitor; (lanes 4-9) Est 1$\Delta 10$ protein to Est $1-\Delta 15$ protein, deleted for amino acids $9-32$, 41-156, 159-323, 323-431, 435-565, and 569-699, respectively; (lane 10) eluate from a mock-prepared extract. Although the proteins purified from these six deletion derivatives showed the expected reduction in size on SDS-PAGE gels, the complexes formed with telomeric DNA exhibited the same mobility as complexes formed with the intact protein. However, more substantial truncations in the size of Estlp did alter the mobility of the protein-DNA complex (data not shown). 
erogeneous nuclear ribonucleoprotein (hnRNP) family (McKay and Cooke 1992a,b; Ishikawa et al. 1993). These proteins bind even more tightly to similarly sized singlestranded RNA oligomers corresponding in sequence to telomeric repeats. To test whether Estlp behaved in a similar manner, a $r\left(G_{1-3} U\right)$ oligonucleotide, corresponding in sequence to the d(TGTGTGGG) $)_{3}$ telomeric DNA oligonucleotide used in the above experiments, was synthesized in vitro and tested for binding to Est1. In contrast to the vertebrate hnRNP proteins, Estlp showed no ability to form complexes with this ribo-oligonucleotide (Fig. 6A). However, Estl protein did exhibit a general RNA binding activity with a variety of larger RNA substrates; complex formation with 197 and 220 nucleotide RNAs are shown in Figure 6A and C. The ability of Estlp to bind seven RNAs of unrelated sequence ranging in size from $\sim 200$ nucleotides to $1.3 \mathrm{~kb}$ (Fig. 6 and data not shown) argued that binding was nonspecific with regard to sequence. In addition, binding was independent of whether the RNA transcript encoded a telomerase RNA or not. Figure 6A and C show binding to the 197 nucleotide Euplotes telomerase RNA and a 220 nucleotide transcript of unrelated sequence; competition experiments revealed no preference between these two substrates. Furthermore, no enhanced binding to the 1300 nucleotide yeast telomerase TLC1 RNA was observed, relative to the six other RNA substrates tested (data not shown). Although we cannot rule out the possibility that lack of specific binding to the yeast telomerase RNA was attributable to improper folding of this RNA in these experiments, these data indicate that Estlp interacts with RNA in a nonspecific manner in vitro.

To determine the region of Est $1 p$ required for RNA complex formation, the same deletion panel used to localize telomeric DNA binding was also assayed for RNA binding. Estlp- $\Delta 14$, which was defective for DNA binding (Fig. 5), also completely abolished RNA gel-shift activity (data not shown). As RNA and DNA binding mapped to the same general region of the protein, this suggested that RNA binding might be simply a nonspecific artifact of DNA binding. To investigate this, we asked whether the binding sites for these two nucleic acids were the same by assaying whether RNA was capable of competing for telomeric DNA binding. Figure 6B shows that a 1000- to 10,000-fold molar excess of cold RNA had little effect on telomeric DNA binding. Two different RNA species that bind Estlp were used as competitors, one of which was the TLC1 yeast telomerase RNA. The lack of competition was not attributable to reduced ability of Estlp to bind RNA; in fact, as shown in Figure 6C, the affinity of Estlp for RNA was $50 \mathrm{~nm}$, fivefold higher than the affinity for telomeric DNA. Therefore, although RNA and DNA binding map to the same region of the Estl protein, the two nucleic acid binding activities appear to be functionally distinct.

\section{EST1 functions in the same pathway for telomere replication as TLC1}

The above telomeric DNA binding data, combined with
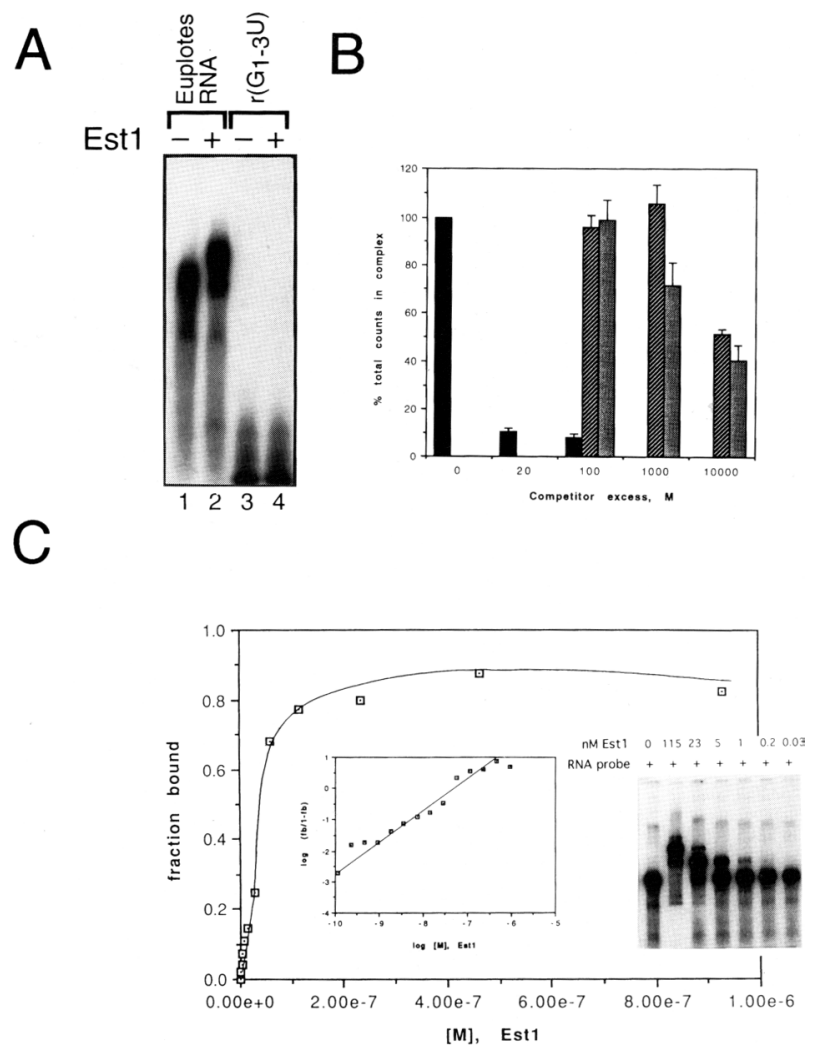

Figure 6. Estl protein binds RNA nonspecifically. RNA gel shifts were performed as described in Materials and Methods; Est 1 protein was at $20 \mathrm{nM}$ and all RNA substrates at $500 \mathrm{pM} .(A)$ Binding to the 197 nucleotide Euplotes telomerase RNA is compared with the absence of binding to a 27 nucleotide $r\left(\mathrm{G}_{1-3} \mathrm{U}\right)$ substrate. $(B)$ Quantitation by PhosphorImager analysis of telomeric DNA gel shifts, with 50 pM of d(TGTGTGGG) ${ }_{3}$ telomeric oligo and $200 \mathrm{~nm}$ Estl protein, in the presence of cold competitors added from 20- to 10,000-fold molar excess; four independent gel-shift assays were quantitated for each competition experiment. $d\left(G_{1-3} T\right)=d(T G T G T G G G)_{3}$, RNA no. $1=1100$ nucleotide transcript synthesized from linearized pBluescript, and RNA no. $2=1300$ nucleotide TLC1 yeast telomerase RNA. (Solid bars) $\mathrm{d}_{(}\left(\mathrm{G}_{1-3} \mathrm{~T}\right)$; (hatched bars) RNA no. 1; (shaded bars) RNA no. 2 (TLC1). (C) The dissociation constant for RNA binding was determined from PhosphorImager analysis of four independent gel mobility shifts using an adenovirus 220 nucleotide RNA transcript at a fixed concentration of $50 \mathrm{pM}$, with Estl concentration varied from 0 to $115 \mathrm{~nm}$. The equilibrium curve is plotted as the fraction of RNA bound vs. EST1 concentration; the Hill plot and a representative RNA gel shift are shown as inserts.

the telomere-specific phenotype of est1 mutations, suggests that Estlp binds to the end of the chromosome in vivo. Another activity in yeast that has also been shown to bind to single-stranded telomeric oligos is yeast telomerase (Cohn and Blackburn 1995; Lin and Zakian 1995; Lue and Wang 1995). Null mutations of either TLC1 (encoding the yeast telomerase RNA) or EST1 have been observed previously to have very similar effects on telomere length and cell viability (Lundblad and Szostak 
1989; Singer and Gottschling 1994; Lendvay et al. 1996). To test whether this reflects a requirement for these two genes in the same pathway of telomere replication, we examined the phenotype of a strain carrying deletions of both EST1 and TLC1. If these two genes function in two separate pathways, each necessary for telomere function, a double mutant strain would be expected to show an enhancement of phenotype, relative to either single mutant. Figure 7A shows that the decline in cell viability seen in est1- $\Delta$ and $t l c 1-\Delta$ strains was indistinguishable from that displayed by the est1- $\Delta$ tlc1- $\Delta$ double mutant. Similarly, telomere length in these three strains showed the same reduction over time (data not shown). Therefore, elimination of either EST1 or TLC1 gene function has identical and nonadditive effects on telomere replication.

Overexpression of certain mutant derivatives of either EST1 or TLC1 also have similar effects on telomeric silencing and telomere length maintenance. TLC1 was uncovered unexpectedly in a genetic screen for cDNAs that, when overexpressed in a wild-type strain, relieved telomeric silencing (Singer and Gottschling 1994); overexpression of the TLC1 clones also moderately decreased telomere length. Because none of the TLC1 isolates were full length, Singer and Gottschling proposed that these partial RNA molecules were acting as dominant-negative suppressors, possibly by titrating limiting components of either telomerase or the silencing machinery. Figure 7 shows that increased expression of mutant derivatives of EST1 had a similar dominant-negative effect on both telomeric silencing and telomere length maintenance. The est 1 mutations used in this experiment were two missense mutations $\left(e s t 1_{\mathrm{F} 511 \mathrm{~s}}\right.$ and est $_{\mathrm{D} 5131}$ ) that were defective for EST activity when either of these mutant alleles were the only copy of EST1 present in the cell (data not shown). Overexpression of either of these two est 1 mutant proteins in a wild-type strain strongly suppressed telomeric silencing (Fig. 7B), and the level of suppression correlated with the activity that each allele displayed in vivo in a complementation assay (data not shown).

In addition to the silencing phenotype, overexpression of these two Estl mutant proteins shortened telomeres by $\sim 80-150 \mathrm{bp}$ (Fig. $7 \mathrm{C}$ ), similar to that reported for overexpression of TLC1 derivatives in wild-type yeast (Singer and Gottschling 1994). Because overexpression of wildtype EST1 does not affect either telomere length or telomeric silencing substantially, one explanation for the behavior of these est 1 missense mutations could be attributable to titration of a limiting component. However, this hypothesized factor does not appear to be the yeast telomerase RNA alone, as increased expression of TLC1 does not suppress the dominant negative effects of either est 1 missense mutation on telomere length (data not shown).

\section{Discussion}

Although EST1 was shown seven years ago to have a critical role in telomere maintenance (Lundblad and Szostak 1989), its precise function at the telomere has remained unclear. In this study, we have addressed this by studying the Est1 protein in isolation. This approach has demonstrated that purified Estlp has the properties expected of a terminus-binding protein and thereby provides evidence for a specific role for Est 1 protein at the telomere. The identification of a single-stranded telomere-binding protein in a genetically tractable system such as yeast has now allowed an assessment of the in vivo role of this class of proteins. We have shown that a genetic comparison between EST1 and TLC1 places both of these genes in the same genetically defined pathway for telomere replication. Furthermore, as the phenotypes of an est1- $\Delta$ strain are as severe as a tlc1- $\Delta$ strain (Lundblad and Szostak 1989; Singer and Gottschling 1994), this indicates that Estlp activity is as essential for telomerase function in vivo as is the core enzyme itself.
A
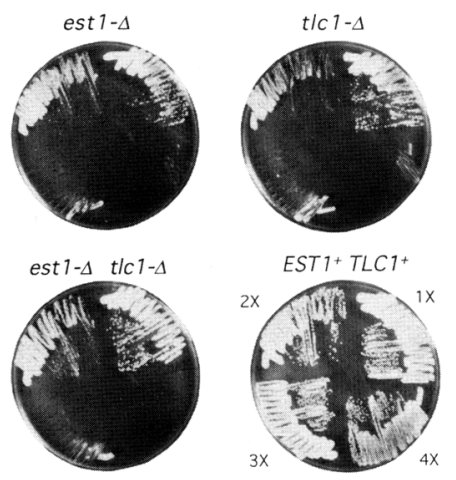
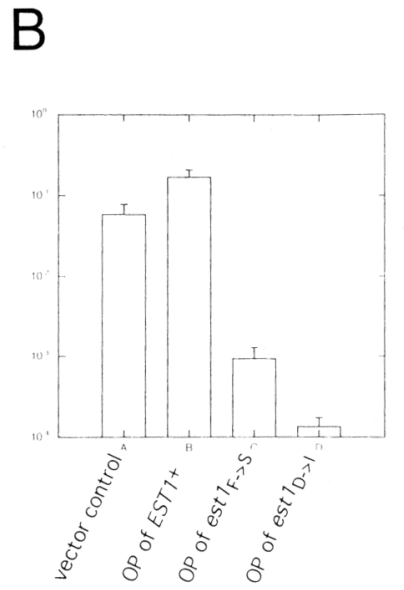
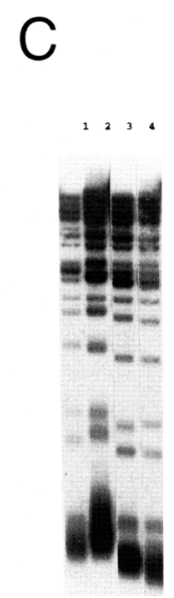

Figure 7. EST1 and $T L C 1$ function in the same pathway for telomere replication. $(A)$ Viability of est1- $\Delta 3:: H I S 3$, tlc1- $\Delta:: L E U 2$,

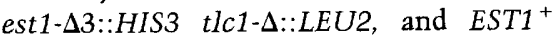
$T L C 1^{+}$haploid strains, shown as four successive streak-outs (indicated as $(\times-4 \times$ ) on YPD plates, differing from each other by $\sim 25$ generations of growth. $(B)$ Overexpression of either of two est 1 mutant proteins strongly relieves telomeric silencing of a URA3 gene placed at telomere VII-L, as indicated by the fraction of cells able to grow in the presence of 5-FOA, which is toxic to cells expressing $U R A 3^{+}$. Three single colonies for each were assayed; (OP) overproduction. $(C)$ Southern blot of genomic yeast DNA, probed with a telomere-specific probe. $E S T 1^{+}{ }^{+} L C 1^{+}$strain with either (Lane

1) the parental pADH expression vector; (lane 2) wild-type $E S T 1^{+}$expressed from a pADH promoter; (lane 3) est1-6 (est $\left.1_{\mathrm{F} 511 \mathrm{~S}}\right)$ expressed from a pADH promoter; (lane 4 ) est1-7 (est $1_{\mathrm{D} 5131}$ ) expressed from a pADH promoter. 
However, the fact that telomerase activity is present in extracts prepared from an est $1-\Delta$ strain /Cohn and Blackburn 1995) argues that Estlp is not essential for enzymatic activity. Therefore, we propose that Estlp functions, via its single-stranded DNA binding activity, to direct telomerase to the chromosomal terminus, an activity that is essential in vivo but dispensable in vitro.

There are a number of functional similarities between Est $1 \mathrm{p}$ and other single-stranded telomere binding proteins, suggesting that Estlp mediates telomerase access as a component of telomeric chromatin. Like these other proteins, Estlp binding is dictated by both the structure and sequence of the $3^{\prime}$ terminus of the DNA substrate. Conversion to a molecule that is partially duplex at the 3 ' end eliminates complex formation for both Est $1 \mathrm{p}$ and terminus-binding factors identified in Xenopus egg extracts and Tetrahymena extracts (Cardenas et al. 1993; Sheng et al. 1995). Similarly, the Oxytricha and Euplotes proteins require a single-stranded extension to form a telomeric complex (Gottschling and Zakian 1986; Price and Cech 1987; Price 1990). In addition, all of these telomere binding proteins show sequence-specific binding, with the highest affinity for the telomeric repeat sequence of the species from which the binding protein was identified. Estlp similarly shows relatively high sequence specificity; although it binds Oxytricha telomeric sequences roughly as well as a yeast telomeric substrate, it shows little or no binding to human or Tetrahymena telomeric substrates. This contrasts sharply with how telomerase recognizes and elongates telomeric primers, as this enzyme, when isolated from a number of different sources, does not differentiate between telomeric primers from different species /Greider and Blackburn 1985; Morin 1989; Shippen-Lentz and Blackburn 1990; Harrington et al. 1995).

An alternative possibility is that Estlp is a noncatalytic component of the telomerase complex. Support for this proposal has come from experiments that monitored the association of this protein with the TLC1 telomerase RNA, although these experiments did not assess whether Estlp was present in a 1:1 ratio with the telomerase RNA (Lin and Zakian 1995; Steiner et al. 1996). Our results have demonstrated that Est $1 p$ has a strong RNA binding activity in vitro, with no preference for the yeast telomerase RNA. This raises questions about the specificity of the in vivo interaction between Estlp and the TLC1 RNA, which is underscored by the observation that Estlp immunoprecipitates prepared from a strain deleted for TLC1 still exhibit an RNase-sensitive DNA polymerizing activity (Steiner et al. 1996). One model that could reconcile these observations is to propose that Est $1 p$ has a functional but nonspecific RNA binding activity in vivo, with specificity conferred by its location at the telomere. Resolution of a possible in vivo role for Est1 RNA binding will require additional investigation, such as the identification of missense mutants of Estlp that fail to bind RNA in vitro; such mutants can be used to ask whether they exhibit an in vivo telomere maintenance defect and/or altered association with the enzyme.
It is likely that the yeast Estl protein interacts with other factors as part of its telomere end-binding activity. One potential candidate is the $\mathrm{Cdc} 13$ protein, previously shown to have a critical role in telomere metabolism (Garvik et al. 1995). We have shown recently that Cdc13p is also a G-rich single-stranded telomere binding protein with a role in mediating, either directly or indirectly, access of telomerase to the chromosomal terminus (Nugent et al. 1996). However, although both Estlp and Cdc $13 p$ specifically bind yeast single-stranded telomeric substrates, only Est $1 p$ requires a free $3^{\prime}$ end. This suggests that although both proteins participate in mediating the access of telomerase to the telomere, Estlp may be more critical in bringing the enzyme to the actual $3^{\prime}$ terminus. One potential long-range consequence of this model may be relevant to cancer treatment; because reactivation of telomerase has been proposed to be critical for tumor progression (de Lange 1994; Morin 1995; Shay and Wright 1996), blocking access of the enzyme to the telomere may provide an alternative target for therapeutic intervention, as opposed to inhibition of enzyme activity.

Regulation of both telomerase and other enzymatic activities that act at the telomere is poorly understood at the molecular level. Therefore, identification and characterization of components in a genetic system such as the yeast $S$. cerevisiae may help elucidate this process. Recently, this approach has led to the identification of three additional EST genes that function in the same pathway for telomere replication as TLC1 and EST1 (Lendvay et al. 1996). Characterization of these components in both lower and higher eukaryotes, in addition to analysis of the enzyme telomerase, may be necessary to fully understand the relationship between telomere length and growth control, and the consequences for cellular aging and cancer.

\section{Materials and methods}

Strains and plasmids

The yeast strain, DVL32 (MATa/MAT $\alpha$ est1- $\triangle 1:: H I S 3 / E S T 1^{+}$ tlc1- $\Delta:: L E U 2 / T L C 1^{+}$ura3-52/ura3-52 Iys2-801/lys2-801 ade2101/ade2-101 trp1- $\Delta 1 / \operatorname{trp} 1-\Delta 1$ his3- $\Delta 200 / h i s 3-\Delta 200$ leu2- $\Delta 1 /$ leu2- $\Delta 1$ ) used for phenotype analysis of est $1-\Delta$ and $11 c 1-\Delta$ was constructed from TVL120 (Lundblad and Szostak 1989), by introduction of $t I c 1-\Delta:: L E U 2$, which removes sequences between nucleotides 192 and 909 of the TLC1 gene. Yeast strain UCC41

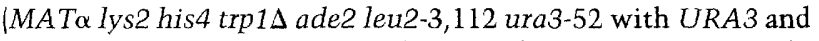
$A D E 2$ at telomere VII-L; Gottschling et al. 1990) was generously provided by Dan Gottschling.

Vectors for expression of EST1 in E. coli were derived from pRSETA (Invitrogen). pVL244 contains the EST1 coding sequence ligated into the BamHI and PstI sites of the pRSETA polylinker, to generate a recombinant protein with 40 amino acids at the amino terminus, including six histidine residues and a 12-amino-acid gene 10 epitope. Although we have not tested this recombinant version of Est 1 in vivo, we have shown that a number of very similar amino-terminal tagged versions of Estl (including versions with $\mathrm{HIS}_{6}$ tags) are fully functional in 
yeast. pVL247 was constructed by inserting EST1 into the NdeI site of pRSETA for a carboxy-terminal tag containing 50 amino acids. In-frame deletions of EST1 (pVL280 to pVL285, containing est $1-\Delta 10$ to est $1-\Delta 15$ ) were initially constructed in pVL247 and subsequently transferred into pVL244. Deletions were constructed using available restriction sites and linker oligos to maintain the coding frame; est1- $\Delta 10$ was deleted between $\mathrm{Hpal}$ and NsiI, removing amino acids $9-32$; est $1-\Delta 11$ was deleted between NsiI and NruI, removing amino acids $41-156$; est $1-\Delta 12$ was deleted between $\mathrm{NruI}$ and $\mathrm{ClaI}$, removing amino acids 159 323; est $1-\Delta 13$ was deleted between ClaI and EcoRV, removing amino acids $323-431$; est $1-\Delta 14$ was deleted between sites EcoRV and BsmI, removing amino acids 435-565; and est 1- $\Delta 15$ was deleted between BsmI and the UGA termination codon, removing amino acids 569-699. For in vivo complementation assays (see Genetic Analysis, below), est1 deletions were transferred into pVL145 (a YCp-TRP1-EST1 vector). The two missense mutations, est1-6 (est $1_{\mathrm{F} 511 \mathrm{~s}}$ ) and est1-7 (est $1_{\mathrm{D} 513 \mathrm{I}}$ ), were created by oligo-directed single-stranded mutagenesis (V.L. and E.H. Blackburn, unpubl.) in pVL198 (a pUCl18 derivative containing CEN3, TRP1ARS1, and the $2.58 \mathrm{~kb}$ EST1 genel. For the overexpression studies, EST1 ${ }^{+}$, est 1-6, and est1-7 were cloned into pVL248 [derived from the $2 \mu$ vector YEplac1 12 /Gietz and Sugino 1988), with an inserted pADH promoter and terminator] to generate pVL249, pVL305, and pVL306, respectively.

\section{Genetic analysis}

Analysis of telomere length and the senescence phenotype were monitored as described previously (Lundblad and Szostak 1989; Lendvay et al. 1996). All haploid strains were generated by tetrad dissection of DVL132 and grown in parallel. The est1-6, est $1-7$, est $1-\Delta 12$, est $1-\Delta 13$, est $1-\Delta 14$, and est $1-\Delta 15$ mutations were assayed for in vivo activity in the absence of $E S T 1^{+}$gene function by introduction of each mutant version on a YCp vector into an est $1-\Delta 3$ haploid yeast strain, in parallel with YCp and YCp-EST1 ${ }^{+}$control vectors. Two to three transformants for each plasmid were assayed for the ability to complement the growth phenotypes of the est $1-\Delta$ strain. To assay for dominant effects of est1-6 and est1-7, each mutant derivative, when expressed from the pADH promoter, was introduced into a wildtype $E S T 1^{+}$strain, along with parental control vectors. Three to four transformants were assayed for telomere length and for relief of transcriptional repression of a telomere-located URA3 gene, as described previously (Gottschling et al. 1990).

\section{Purification of Est1 protein}

Expression in E. coli of EST1 from a T7-regulated expression vector (pVL244 or pVL247) was induced by infection with a recombinant $\mathrm{M} 13$ phage carrying a cloned copy of the T7 RNA polymerase (Stratagene). Est lp was purified as a soluble recombinant protein using the $(\mathrm{His})_{6}$ tag present at either the amino or carboxyl terminus, using immobilized metal affinity chromatography purification with Ni-NTA-Agarose (Qiagen) and elution with $250 \mathrm{~mm}$ imidizole $\{\mathrm{pH} 7.0\}$. The column was washed with a step-gradient of imidizole $(10 \mathrm{mM}, 20 \mathrm{mM}$, and 40 mM imidizole) prior to the elution to remove any bound $E$. coli proteins, which resulted in an enhancement of purity as determined by Coomassie staining. The eluted purified protein was concentrated and washed using Amicon 30 ultrafiltration microconcentrators. Mock protein preps were prepared from a strain carrying a vector with no insert. Protein concentrations were determined using Bradford analysis (Bio-Rad), and immunological detection of the recombinant Est1 protein used antigene 10 antisera (Novagen) to detect a T7 gene 10 epitope fused in frame at either the amino or carboxyl terminus, with visualization with ECL reagents (Amersham) and autoradiography.

\section{Electrophoretic gel shift assays}

Telomeric DNA gel shifts were performed in $10 \mathrm{~mm} \mathrm{HEPES} \mathrm{pH}$ 7.8 , $75 \mathrm{~mm} \mathrm{KCl}, 2.5 \mathrm{~mm} \mathrm{MgCl}_{2}, 0.1 \mathrm{~mm}$ EDTA, $1 \mathrm{~mm} \mathrm{DTT}, 3 \%$ ficoll, and $200 \mu \mathrm{g} / \mathrm{ml}$ poly[d(I-C)] (Pharmacia). Incubations were performed in $10 \mu \mathrm{l}$ reaction volumes with $200 \mathrm{nM}$ of Estl protein, end-labeled single-stranded oligonucleotides (boiled at $95^{\circ} \mathrm{C}$ for $5 \mathrm{~min}$ and snap cooled on ice just prior to use) and competitors, when added. To assay the effect of competitors, Est 1 protein and cold competitors in the above gel shift buffer were incubated at $25^{\circ} \mathrm{C}$ for $5-10 \mathrm{~min}$; after addition of labeled oligo, reactions were further incubated for 15-20 min prior to loading. Reactions were electrophoresed through a $5 \%$ nondenaturing polyacrylamide gel in $1 \times \mathrm{TBE}$ at $250 \mathrm{~V}$. The RNAbinding reactions were performed in the same gel shift buffer as above, but heparin (Sigma) was used as the nonspecific competitor at a final concentration of $1 \mathrm{mg} / \mathrm{ml}$, in place of poly $[\mathrm{d}(\mathrm{I}-\mathrm{C})]$.

\section{DNA/RNA substrates and competitors}

DNA oligonucleotides were synthesized and purified by denaturing gel electrophoresis by Genosys Biotechnologies, Inc. For duplex substrates, oligonucleotides were diluted to $10 \mathrm{mM}$ and annealed in $10 \mathrm{~mm}$ Tris- $\mathrm{HCl}(\mathrm{pH} 7.5), 100 \mathrm{~mm} \mathrm{NaCl}$, and $1 \mathrm{~mm}$ EDTA by heating to $100^{\circ} \mathrm{C}$ for 1 min followed by slow cooling to room temperature. Single-stranded oligos were 5 ' end-labeled with $\left[\gamma^{-32} \mathrm{P} \mid \mathrm{ATP}\right.$ and T4 polynucleotide kinase. The duplex substrate used in Figure $1 \mathrm{C}$ was prepared by annealing end-labeled $\mathrm{d}\left(\mathrm{C}_{1-3} \mathrm{~A}\right)$ to cold $\mathrm{d}\left(\mathrm{G}_{1-3} \mathrm{~T}\right)$. The partially duplex 5' molecule used in Figure 3 (lanes 7 and 8 ) was prepared by annealing two oligos $\left[\left(5^{\prime} \mathrm{R}\right)-\mathrm{Ye}\right.$ and $\left.5^{\prime} \mathrm{R}\right]$ and introducing two $\left[\alpha^{-32} \mathrm{P}\right] \mathrm{dGTP}$ nucleotides with Klenow; the labeled product was subsequently checked on a sequencing gel for the expected two-nucleotide increase in size of the $5^{\prime} \mathrm{R}$ oligo. The partially duplex $3^{\prime}$ molecule used in Figure 3 (lanes 15 and 16 ) was prepared by annealing $5^{\prime}$-end-labeled $3^{\prime} R$ oligo to cold Ye- $\left(3^{\prime} \mathrm{R}\right)$. Labeled DNAs were isolated using NucTrap probe purification columns (Stratagene).

RNA transcripts were synthesized using the MAXIscript in vitro transcription kit (Ambion) using T7, T3, or SP6 polymerase, either in the presence of $\left[\alpha^{-32}\right.$ P $\}$ UTP or with unlabeled ribonucleotides for use as a competitor. Transcripts were purified by NucTrap probe purification columns (Stratagene) or denaturing acrylamide gel electrophoresis and diluted to $500 \mathrm{pm}$ or $0.005 \mathrm{pmole} / \mathrm{reaction}$, heat denatured and snap cooled prior to use in gel shift assays. The 197-nucleotide Euplotes telomerase RNA (Shippen-Lentz and Blackburn 1990) and the S. cerevisiae TLC1 telomerase RNA (Singer and Gottschling 1994) were synthesized from PCR products with incorporated T7 promoter sites, and $\left.r \mid G_{1-3} U\right)$ was synthesized from two DNA oligo primers annealed together with an incorporated $\mathrm{T} 7$ promoter. The adenovirus construct was generously provided by Sue Berget; adenovirus RNA was synthesized from a SP6 promoter as a run off transcript of BamHI-digested DNA to generate a 220 nucleotide RNA product.

\section{Acknowledgments}

We thank J. Angelson, S. Berget, T. Wensel, M. Singer, and D. Gottschling for helpful advice and/or strains, and L. Zumstein and $\mathrm{H}$. Nelson for critical reading of the manuscript. This work was supported by a National Institutes of Health NRSA fellowship to V.V.-P., predoctoral support from the Cullen Endow- 
ment Scholarship Fund to D.K.M., and a National Institutes of Health grant AG11728-01X and an ACS Junior Faculty Research Award to V.L.

The publication costs of this article were defrayed in part by payment of page charges. This article must therefore be hereby marked "advertisement" in accordance with 18 USC section 1734 solely to indicate this fact.

\section{References}

Blackburn, E.H. and C.W. Greider. 1995. Telomeres. Cold Spring Harbor Laboratory Press, Cold Spring Harbor, NY.

Brown, W.R.A. 1989. Molecular cloning of human telomeres in yeast. Nature 338: 774-776.

Cardenas, M.E., A. Bianchi, and T. de Lange. 1993. A Xenopus egg factor with DNA-binding properties characteristic of terminus-specific telomeric proteins. Genes \& Dev. 7:883894.

Cohn, M. and E.H. Blackburn. 1995. Telomerase in yeast. Science 269: 396-400.

Collins, K., R. Kobayashi, and C.W. Greider. 1995. Purification of Tetrahymena telomerase and cloning of genes encoding two protein components of the enzyme. Cell 81: 677-686.

de Lange, T. 1994. Activation of telomerase in a human tumor. Proc. Natl. Acad. Sci. 91: 2900-2904.

Fang, G. and T.R. Cech. 1991. Molecular cloning of telomerebinding proteins from Stylonychia mytilis. Nucleic Acids Res. 19: 5515-5518.

- 1995. Telomere proteins. In Telomeres (ed. E.H. Blackburn and C.W. Greider), pp. 69-105. Cold Spring Harbor Laboratory Press, Cold Spring Harbor, NY.

Fang, G., J.T. Gray, and T.R. Cech. 1993. Oxytricha telomerebinding protein: Separable DNA-binding and dimerization domains of the $\alpha$ subunit. Genes \& Dev. 7: 870-882.

Feng, I., W.D. Funk, S.-S. Wang, S.L. Weinrich, A.A. Avilion, C.-P. Chiu, R.R. Adams, E. Chang, R.C. Alsopp, J. Yu, et al 1995. The RNA component of human telomerase. Science 269: 1236-1241.

Garvik, B., M. Carson, and L. Hartwell. 1995. Single-stranded DNA arising at telomeres in $c d c 13$ mutants may constitute a specific signal for the RAD9 checkpoint. Mol. Cell. Biol. 15: 6128-6138.

Gietz, R.D. and A. Sugino. 1988. New yeast-Escherichia coli shuttle vectors constructed with in vitro mutagenized yeast genes lacking six-base pair restriction sites. Gene 74: 527534.

Gottschling, D.E. and V.A. Zakian. 1986. Telomere proteins: Specific recognition and protection of the natural termini of Oxytricha macronuclear DNA. Cell 47: 195-205.

Gottschling, D.E., O.M. Aparicio, B.L. Billington, and V.A. Zakian. 1990. Position effect at $S$. cerevisiae telomeres: Reversible repression of Pol II transcription. Cell 63: 751-762.

Gray, J.T., D.W. Celander, C.M. Price, and T.R. Cech. 1991 Cloning and expression of genes for the Oxytricha telomerebinding protein: Specific subunit interactions in the telomeric complex. Cell 67: 807-814

Greider, C.W. 1996. Telomere length regulation. Annu. Rev. Biochem. 65: 337-365.

Greider C.W. and E.H. Blackburn. 1985. Identification of a specific telomere terminal transferase activity in Tetrahymena extracts. Cell 43: 405-413.

- 1989. A telomeric sequence in the RNA of Tetrahymena telomerase required for telomere repeat synthesis. Nature 337: $331-337$

Harrington, L., C. Hull, J. Crittenden, and C. Greider. 1995. Gel shift and UV cross-linking analysis of Tetrahymena telo- merase. J. Biol. Chem. 270: 8893-8901

Henderson, E. 1995. Telomere DNA structure. In Telomeres (ed. E.H. Blackburn and C.W. Greider), pp. 11-34. Cold Spring Harbor Laboratory Press, Cold Spring Harbor, NY.

Henderson, E.R. and E.H. Blackburn. 1989. An overhanging 3' terminus is a conserved feature of telomeres. Mol. Cell. Biol. 9: $345-348$.

Ishikawa, F., M.J. Matunis, G. Dreyfuss, and T.R. Cech. 1993. Nuclear proteins that bind the pre-mRNA 3 ' splice site sequence $r\left(U U_{A G} / G\right)$ and the human telomeric DNA sequence d(TTAGGG) $\}_{n}$. Mol. Cell. Biol. 13: 4301-4310.

Klobutcher, L.A., M.T. Swanton, P. Donini, and D.M. Prescott. 1981. All gene-sized DNA molecules in four species of hypotrichs have the same terminal sequence and an unusual $3^{\prime}$ terminus. Proc. Natl. Acad. Sci. 78: 3015-3019.

Konkel, L.M., S. Enomoto, E.M. Chamberlain, P. McCune-Zierath, S.J.P. Iyadurai, and J. Berman. 1995. A class of singlestranded telomeric DNA-binding proteins required for Raplp localization in yeast nuclei. Proc. Natl. Acad. Sci. 92: 5558-5562.

Lendvay, T., D.K. Morris, J. Sah, B. Balasubramanian, and V. Lundblad. 1996. Senescence mutants of Saccharomyces cerevisiae with a defect in telomere replication identify three additional EST genes. Genetics 144: 1399-1412.

Lin, J.-J. and V.A. Zakian. 1994. Isolation and characterization of two Saccharoymces cerevisiae genes that encode proteins that bind to $\left(\mathrm{TG}_{1-3}\right)_{n}$ single strand telomeric DNA in vitro. Nucleic Acids Res. 22: 4906-4913.

_- 1995. An in vitro assay for Saccharomyces telomerase requires EST1. Cell 81: 1127-1135.

Lue, N.F. and J.C. Wang. 1995. ATP-dependent processivity of a telomerase activity from Saccharomyces cerevisiae. 1. Biol. Chem. 270: 21453-21456.

Lundblad, V. and J.W. Szostak. 1989. A mutant with a defect in telomere elongation leads to senescence in ycast. Cell 57: 633-643.

Lustig, A.J. 1992. Hoogsteen $\mathrm{G}_{\mathrm{r}}$-G base pairing is dispensable for telomere healing in yeast. Nucleic Acids Res. 20:30213028.

McEachern, M.J. and E.H. Blackburn. 1995. Runaway telomere elongation caused by telomerase RNA gene mutations. $\mathrm{Na}$ ture 376: 403-409.

McKay, S.J. and H. Cooke. 1992a. A protein which specifically binds to single-stranded TTAGGG $\mathrm{F}_{\mathrm{n}}$ repeats. Nucleic Acids Res. 20: 1387-1391.

- 1992b. hnRNP A2/B1 binds specifically to singlestranded vertebrate telomeric repeat TTAGGG ${ }_{\mathrm{n}}$. Nucleic Acids Res. 20: 6461-6464.

Mantell, L.L. and C.W. Greider. 1994. Telomerase activity in germline and embryonic cells of Xenopus. EMBO J. 13: $3211-3217$

Morin, G.B. 1989. The human telomere terminal transferase enzyme is a ribonucleoprotein that synthesizes TTAGGG repeats. Cell 59: 521-529.

- Is telomerase a univeral cancer target? I. Natl. Cancer Inst. 87: 859-861.

Nugent, C., T.R. Hughes, N.F. Lue, and V. Lundblad. 1996. Cac13p: A single-strand telomeric DNA binding protein with a dual role in yeast telomere maintenance. Science 274: 249-252.

Pluta, A.F., B.P. Kaine, and B.B. Spear. 1982. The terminal organization of macronuclear DNA in Oxytricha fallax. $\mathrm{Nu}$ cleic Acids Res. 10: 8145-8154.

Pluta, A.F., G.M. Dani, B.B. Spear, and V.A. Zakian. 1984. Elaboration of telomeres in yeast: Recognition and modification of termini from Oxytricha macronuclear DNA. Proc. Nat1. 
Acad. Sci. 81: 1475-1479.

Price, C.M. 1990. Telomere structure in Euplotes crassus: Characterization of DNA-protein interactions and isolation of a telomere-binding protein. Mol. Cell. Biol. 10: 3421-3431.

1992. Centromeres and telomeres. Curr. Opin. Cell Biol. 4: 379-384.

Price, C.M. and T.R. Cech. 1987. Telomeric DNA-protein interactions of Oxytricha macronuclear DNA. Genes \& Dev. 1: 783-793.

Prowse, K.R., A.A. Avilion, and C.W. Greider. 1993. Identification of a nonprocessive telomerase activity from mouse cells. Proc. Natl. Acad. Sci. 90: 1493-1497.

Shampay, J., J.W. Szostak, and E.H. Blackburn. 1984. DNA sequences of telomeres maintained in yeast. Nature 310: 154 157.

Shay, J.W. and W.E. Wright. 1996. Telomerase activity in human cancer. Curr. Opin. Oncol. 8: 66-71.

Sheng, H., Z. Hou, T. Schierer, D.L. Dobbs, and E. Henderson. 1995. Identification and characterization of a putative telomere end-binding protein from Tetrahymena thermophila. Mol. Cell. Biol. 15: 1144-1153.

Shippen, D.E., E.H. Blackburn, and C.M. Price. 1994. DNA bound by the Oxytricha telomere protein is accessible to telomerase and other DNA polymerases. Proc. Natl. Acad. Sci. 91: 405-409.

Shippen-Lentz, D. and E.H. Blackburn. 1990. Functional evidence for an RNA template in telomerase. Science 247: 546552.

Singer, M.S. and D.E. Gottschling. 1994. TLC1: Template RNA component of Saccharomyces cerevisiae telomerase. Science 266: 404-409.

Stavenhagen, J.B. and V.A. Zakian. 1994. Internal tracts of telomeric DNA act as silencers in Saccharomyces cerevisiae. Genes \& Dev. 8: 1411-1422.

Steiner, B.R., K. Hidaka, and B. Futcher. 1996. Association of the Est 1 protein with telomerase activity in yeast. Proc. Natl. Acad. Sci. 93: 2817-2821.

Vermeesch, J.R. and C.M. Price. 1994. Telomeric DNA sequence and structure following de novo telomere synthesis in Euplotes crassus. Mol. Cell. Biol. 14: 554-566.

Walmsley, R.M., C.S.M. Chan, B.-K. Tye, and T.D. Petes. 1984. Unusual DNA sequences associated with the ends of yeast chromosomes. Nature 310: 157-160.

Wang, W., R. Skipp, M. Scofield, and C.M. Price. 1992. Euplotes crassus has genes encoding telomere-binding proteins and telomere-binding protein homologs. Nucleic Acids Res. 20: $6621-6629$.

Wellinger, R.J., A.J. Wolf, and V.A. Zakain. 1993. Saccharomyces telomeres acquire single-strand $\mathrm{TG}_{1-3}$ tails late in $\mathrm{S}$ phase. Cell 72: 51-60.

Wellinger, R.J., K. Ethier, P. Labrecque, and V.A. Zakian. 1996. Evidence for a new step in telomere maintenance. Cell 85: 423-433.

Wiley, E.A. and V.A. Zakian. 1995. Extra telomeres, but not internal tracts of telomeric DNA, reduce transcriptional repression at Saccharomyces telomeres. Genetics 139: 67-79.

Yu, G.-L., J.D. Bradley, L.D. Attardi, and E.H. Blackburn. 1990. In vivo alteration of telomere sequences and senescence caused by mutated Tetrahymena telomerase RNAs. Nature 344: 126-132.

Zahler, AM. and D.M. Prescott. 1989. DNA primase and the replication of the telomeres in Oxytricha nova. Nucleic Acids Res. 17: 6299-6317.

Zakian, V.A. 1995. Telomeres: Beginning to understand the end. Science 270: 1601-1607. 


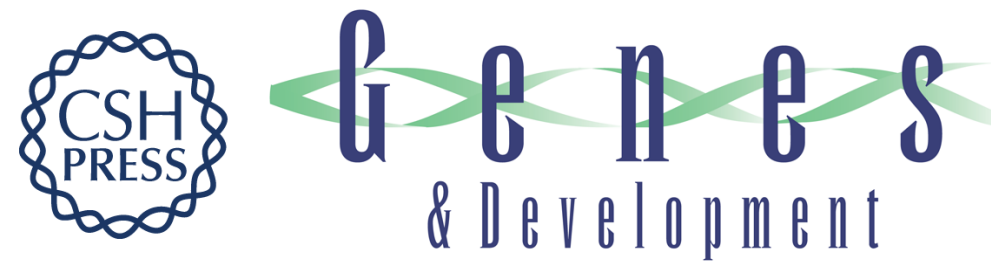

\section{Est1 has the properties of a single-stranded telomere end-binding protein.}

V Virta-Pearlman, D K Morris and V Lundblad

Genes Dev. 1996, 10:

Access the most recent version at doi:10.1101/gad.10.24.3094

References This article cites 56 articles, 27 of which can be accessed free at:

http://genesdev.cshlp.org/content/10/24/3094.full.html\#ref-list-1

License

Email Alerting

Service

Receive free email alerts when new articles cite this article - sign up in the box at the top right corner of the article or click here.

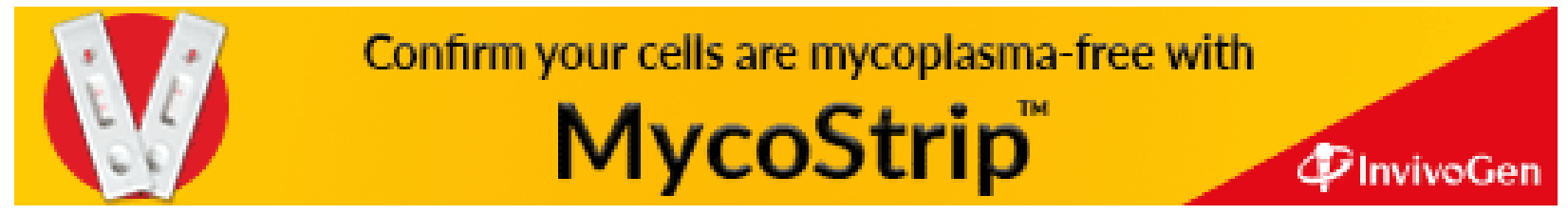

